\title{
The Impact of Weather Factors on Quotations of Energy Sector Companies on Warsaw Stock Exchange
}

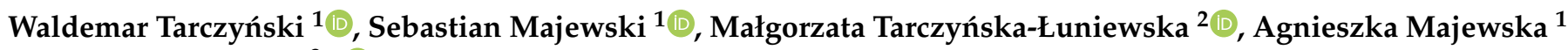 \\ and Grzegorz Mentel ${ }^{3, *(1)}$ \\ 1 Department of Sustainable Finance and Capital Markets, Institute of Economics and Finance, \\ University of Szczecin, 71-101 Szczecin, Poland; waldemar.tarczynski@usz.edu.pl (W.T.); \\ sebastian.majewski@usz.edu.pl (S.M.); agnieszka.majewska@usz.edu.pl (A.M.) \\ 2 Department of Econometrics and Statistics, Institute of Economics and Finance, University of Szczecin, \\ 71-101 Szczecin, Poland; malgorzata.tarczynska@usz.edu.pl \\ 3 Department of Quantitative Methods, The Faculty of Management, Rzeszow University of Technology, \\ 35-959 Rzeszow, Poland \\ * Correspondence: gmentel@prz.edu.pl; Tel.: +48-608-591-330
}

Citation: Tarczyński, W.; Majewski, S.; Tarczyńska-Łuniewska, M.;

Majewska, A.; Mentel, G. The Impact of Weather Factors on Quotations of Energy Sector Companies on Warsaw Stock Exchange. Energies 2021, 14, 1536. https://doi.org/10.3390/ en14061536

Academic Editor: Ricardo J. Bessa

Received: 4 February 2021

Accepted: 5 March 2021

Published: 10 March 2021

Publisher's Note: MDPI stays neutral with regard to jurisdictional claims in published maps and institutional affiliations.

Copyright: (c) 2021 by the authors. Licensee MDPI, Basel, Switzerland. This article is an open access article distributed under the terms and conditions of the Creative Commons Attribution (CC BY) license (https:/ / creativecommons.org/licenses/by/ $4.0 /)$.

\begin{abstract}
Recent researches on behavioral finance have tested for, among others, evidence for the relations between weather, investors' mood, and investment decisions. Many of the researches related to the influence of some weather factors, such as sunshine duration on stock exchange returns, but there is no complex research taking into account a wide group of weather factors determining investors' mood. The main goal of the article is to verify the influence of weather factors on basic market parameters of energy sector companies quoted on the Warsaw Stock Exchange. Rates of return, trading volumes, and values of trading volume are taken into account during the research. All analyses are based on econometric models assuming the existence of typical problems of estimation such as: autocorrelation of residuals, heteroskedasticity, or abnormality of residuals. The best approximation of models was obtained for GARCH (Generalized Autoregressive Conditional Heteroskedasticity) type models.
\end{abstract}

Keywords: weather; energy sector; econometrics; mood; behavioral finance

\section{Introduction}

Climate change is an important element of observation not only in the field of the natural environment but also the economy. An important concept that has developed in connection with climate change and found an important place in the economy is weather risk [1-3]. In general, this type of risk relates to the company's operations to fluctuations in weather factors. The weather factors include temperature, precipitation (rain, snow, hail) and wind strength. Analyzes related to weather factors' impact on the economy (at different levels of aggregation) are widely discussed in the literature on the subject. It has been proven [4] that temperature changes affect the rate of changes in economic growth. The results of these studies indicate that an increase in temperature causes a decrease in production growth, which negatively impacts economic growth. It is also worth noting that various approaches or models are used in this type of research. For example, the DICE (Dynamic Integrated model of Climate and the Economy) model was used for the impact of temperature changes on economic growth. This model was used to investigate the impact of temperature changes on the GDP growth rate [5]. Another approach is the study on estimating the impact of temperature and forecasts of its changes on the profitability of farms [6]. In turn, in Lu et al. [7], time series were used to build the trans-log production function model. The obtained results indicated the negative impact of temperature changes (increase) on regions' economic development.

The interest of researchers in the field of climate change is also evident within the stock market. Behavioral finance is particularly relevant to climate change and weather 
risk. In this case, the key element is the analysis of the impact of climate change on the behavior of investors on the stock market. Research results in this area [8-11] have shown a relationship between weather factors, investor sentiment and investment decisions. For example, Hirshleifer and Shumway [12] wrote about the impact of sunny days in the US on returns from the stock exchange. However, it is impossible not to mention that the first article on this issue was written in 1993 [12] and concerned the study of the influence of the sun on the stock market on the NYSE example. In general, it is worth noting that the information on the impact of changes in weather factors is important for the economy at various levels of aggregation, including the stock market. The article focuses on the study of the impact of weather changes on companies in the energy sector. Attention was paid to investors' behavior resulting from changes in weather factors. In light of behavioral finance, this problem relates to their reaction and making investment decisions through the prism of emotions [13]. In turn, these emotions are strongly related to the investor's mood due to weather changes [14-16]. It is worth mentioning one of the studies that indicated the relationship of weather at all-sunlight on the mood, behavior and emotions of the respondents $[8,17]$. Therefore, weather factors can be treated as information that reaches the investor and is subject to him. The shaping of the investor's behavior influences the picture of the market-visually illustrated by the fluctuation of the prices of financial instruments for which the investor has decided to buy or sell them. It should also be noted that the information on changes in factors is non-financial information and belongs to the category of directly immeasurable factors. For example, it is difficult to directly measure an investor's current mood caused by a change in the weather. However, it can attempt to test the investor's mood through the prism of changes in financial instruments' prices on the market when an investor decides to buy or sell, for example, shares. In this case, investor de facto influence changes in their prices. By combining information on weather factors changes with changes in the prices of financial instruments listed on the stock exchange, one can address the impact of weather factors on investors' behavior.

It is worth noting that the issue of information on the impact of weather factors changes may also be an element of continuing research on the effectiveness of stock markets. The efficient market hypotheses and the mechanisms of market operation and the impact of information on stock exchanges were established by Fama [18]. The development of stock markets and the intensification of work in searching for factors influencing changes in the prices of financial instruments or investors' behavior directed researchers to analyze the influence of weather factors on the shaping of stock markets. The article's main aim is to verify the influence of weather factors on the basic market parameters of energy companies listed on the Warsaw Stock Exchange (WSE). The research used: rates of return, turnover volumes and turnover values for energy companies listed on the WSE. The study used econometric models of time series of the ARCH (Autoregressive Conditional Heteroskedasticity) and GARCH (Generalized Autoregressive Conditional Heteroskedasticity) type. Models of this type assume the occurrence of typical estimation problems such as residual autocorrelation, heteroscedasticity of the random term or residual abnormality. The use of this type of models was justified due to the specificity of the problem studied. The results of the study indicated that the best approximation of the models was obtained for GARCH models. The considerations and results of the research conducted in the article complement the existing research gap in the modelling of changes in the stock market as a result of changes in weather factors. The approach proposed in the article using selected econometric models shows the usefulness of econometric methods and complements the existing state of knowledge in this field. The article was organized as follows. Introduction-being a background for the relationship between weather factors and investors' behavior on the stock market, including their investment decisions. The second chapter on the presentation of the adopted research methodology. This section also includes information on the scope of the study and the data used. The results of the study are presented in the next part. The fourth chapter contains a substantive discussion concerning the obtained research results. 
The article ends with the conclusions, which summarize the research results and indicate the need for their further continuation.

\section{Literature Review}

It is necessary to turn back to the psychology of human behavior to understand the proposed idea of the research is necessary. Many psychologists researched the influence of weather factors on individuals' behavior. It should be underlining such works as Howarth E. and Hoffman M.S.A. They proved there are connections between mood and weather factors. For example, they found that humidity, temperature and hours of sunshine had the greatest effect on mood. It was also very interesting in this work that high levels of humidity lowered concentration and it caused the increase in sleepiness. Another important conclusion in this research was that the temperature has a positive impact on the human mood and humidity is the most significant predictor in regression analysis [13].

Nofsinger J.R. in his book wrote about the influence of unrelated emotions on the making decision process [19]. This unrelation means the emotions, which could not be assigned to any decision. The investor could be in a good mood because of the weather or because the winning of the favorite football team. Such a finding is strictly tied with risk-asfeelings hypothesis by Loewenstein G.F. \& others [20]. The connections between different groups of factors influencing making decision process are presented on the Figure 1. It was shown that even when some of factors have an impact on cognitive valuation, some of them have an impact on feelings, but taking into account feedbacks in relations between cognitive valuation and feelings, many different factors influence on behavior. De facto, it results also other emotions in the end.

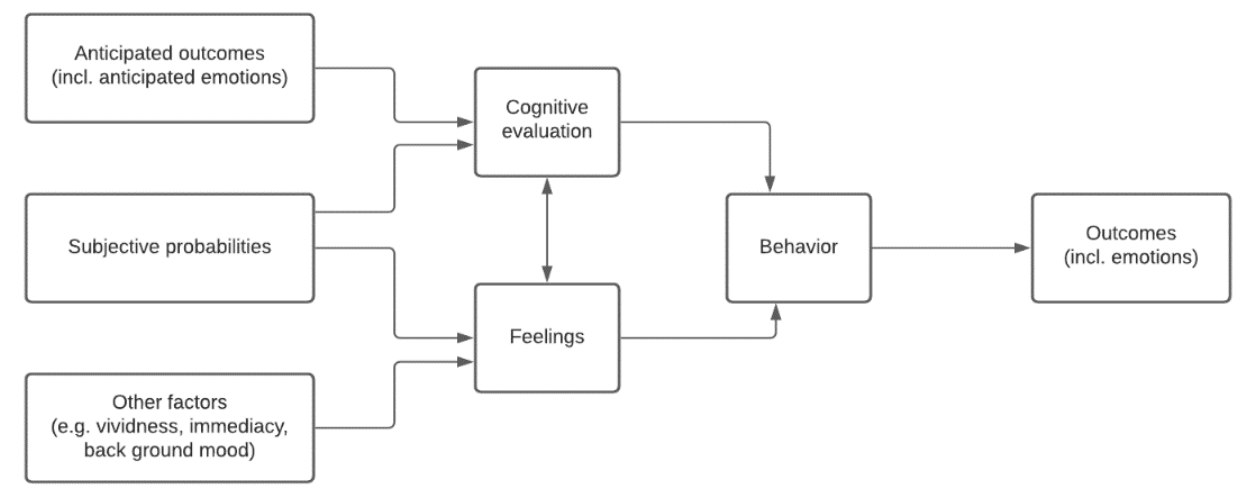

Figure 1. Risk-as-emotions hypothesis. Source: [20].

Presented figure indicates on three premises supporting investment decision (including risk and uncertainty affected by feelings). These groups are as follows:

- Cognitive evaluations inducing emotional reactions-documented by psychologists' researches [21].

- Emotions informing cognitive evaluations-optimistic mood tends to make optimistic judgements and negative-negative judgements [22].

- Feelings affecting individual's behavior-the problem was raised in Damasio's study [23], where it was climbed that emotions play a key-role in the making decision process in terms of uncertainty and risk.

Loewenstein theory is a base for behavioral finance's "misattribution bias" [24], which stands that general well-being and moods could influence on financial decisions [19]. The traditional attempt to finance is based on rational expectations and it assumes that individuals support their investment decisions using fundamental analysis or modern portfolio theory. Such an approach requires to fulfill assumptions connected to methods, tools, and in the first raw market efficiency (EMH). The existence of market efficiency means that every significant information is immediately reflected in the price of financial assets [18]. The discussion point is what does it mean "significant information" and 
"immediately"? However, if there could be any possibility to used econometric models to forecast market prices the market will be merely in the weak form of the efficiency. So, if there are such possibilities, it generates another one question, namely do the level of market development influence on the creation of possibilities for using relations between prices and other, even non-economic, factors. It seems the developing, small or medium markets are more vulnerable on emotional factors [25].

The literature indicates that scientific analyses focusing on the verification of market efficiency or existence of behavioral phenomena are often engaged in explaining relationships between market parameters factors determining emotional reactions of individuals $[15,26,27]$. Thanks to quantitative tools, they try to find indirect relations to enrich supporting financial decision process. Many researches in the last decade focused on the influence of sunshine days on emotions of stock exchange investors [12,16,28]. Various approaches are used in modelling the impact of changes in weather factors on stock markets. In particular, however, it is worth paying attention to the use of certain types of approaches or econometric models. Research $[29,30]$ showed the influence of changes in weather factors on the volatility of shares. The authors verified the hypotheses about these dependencies using MA-MSD methods. Similar results in terms of dependence were obtained in research Kang et al. [31]. In this case, the influence of moon phases on the rates of return on 62 stock markets was examined. The analyzes used a panel fixed effects model. Mugerman, Yidov and Wiener [32], using regression studied the effect of the shift from daylight saving time (summertime) to Standard Time (winter time) on stock markets. In turn, the results Apergis and Gupta [33], indicate that some weather-related, but no seasonal affective disorder related effects on the financial market. Selected regression models were also used in this case. The paper [34] refers to market efficiency, and the empirical study considers the concept of mood beta, an asset's return sensitivity to investor mood variations. The work results indicate the repetition of changes in the prices of shares or equity portfolios when the moods match. Similar results of connections were also obtained in the works [35,36]. Research results [37] indicate that the inclusion of weather variables helps to model the GJR-GARCH process [38-40] in the conditional variance. The authors also referred to as the market efficiency hypothesis and weather anomalies. Frühwirth and Sögner [41] focus on checking the explanatory power of certain weather variables, measured as deviations from their monthly averages, in New York (leading international financial trading centre) for South African stock returns. GARCH models [42,43] and the random walk model were used in the analyzes. Reference was also made to the possibility of forecasting price changes due to changes in weather factors. Better results were obtained for the GARCH model. Research conducted [44] in the Greater China region's stock market also confirmed the existence of links between weather factors, return rates, and share volatility. In analysis were using a mixture of four weather numerically measured variables and five weather forecast dummy variables. The study used different combinations of autoregressive models (e.g., ARCH (Autoregressive Conditional Heteroskedasticity), TGARCH (Threshold GARCH), EGARCH (Exponential GARCH), ARMA (Autoregressive Moving Average)).

The research [45] examined solar and cosmic weather phenomena' influence on the volatility of the SPDR fund price index (XLF). The paper compares the MAPE (Mean Absolute Percentage Error) and RMSFE (Root Mean Squared Forecast Error) forecasting criteria for the ARCH and GARCH autoregressive models. The research results indicated a significant correlation between selected weather factors and changes in the fund's price index. However, the results of studies using autoregressive models give similar results. It is worth noting that the studies try to adapt the models to the conditions and markets they study. Hence, in many works, autoregressive models of various classes are used. As shown in the literature on the subject, there is no clear-cut solution for studying the connections and the impact of weather factors on the stock markets. Therefore, analysts are still looking for methods to describe and model changes resulting from changes in weather factors. This situation means that the issue of conducting research remains topical and worth attention. 


\section{Materials and Methods}

The research was based on the data collected from Warsaw Stock Exchange and Institute of Meteorology and Water Management National Research Institute in Poland. Time series cover the period from January 2010 to December 2020 for seven energy branch companies quoted on the Warsaw Stock Exchange such as: Bedzin CHP Plant in Poznan, Energa in Gdansk, Combined Heat and Power Plants Kogeneracja in Wroclaw, PAK in Konin, Polish Energetic Group in Warsaw, Polenergia in Warsaw and Tauron Polish Energy in Katowice. Three kinds of dependent variables were analyzed in econometric models, describing relations between stocks and weather factors. The role of dependent variables was played by:

- logarithmic rates of return;

- logarithmic changes of trading volume;

- logarithmic changes of trading volume value.

These three variables play role of dependent variables: logarithmic rate of return reflects general investors activity but changes in trading volume and trading value describe emotional reactions of investors [46].

The estimation of econometric models involved following variables:

- logarithmic rates of return (normal and lagged);

- average temperature;

- Sum of falls (mm)

- Sunshine duration (hours)

- Time of rain fall (hours)

- Time of snow fall (hours)

- Time of sleety rain falls (hours)

- Average daily cloudiness (octants)

- Average daily wind speed (meters per second)

- Average daily humidity (\%)

- Average daily pressure (hPa)

Weather factors were collected for main locations of detailed companies. Therefore, database is different for every stock company taking into account both time series length and location of weather station.

The models describing relationships between are based on the simple regression model and residuals are estimated using (G)ARCH-type models. The models described below were analyzed during the research.

The first was estimated model describing dependent variable was the simple regression model calculated with an equation as follows:

$$
y_{t}=\gamma_{0}+\sum_{k=1}^{n} \gamma_{k} X_{k t}+\varepsilon_{t}
$$

where:

$y_{t}$ denotes one of three dependent variables in $t$-time;

$X_{k t}$ is the value of regressor $k$ in period $t$;

$\varepsilon_{t}$ is the random component normally distributed $\mathrm{N}(0,1)$.

$(\mathrm{G}) \mathrm{ARCH}(\mathrm{p}, \mathrm{q})$ models were the best approximants for residuals obtained for simple regression models (1) for described variables.

$\mathrm{ARCH}(\mathrm{q})$ (autoregressive conditional heteroskedasticity) is a type of the econometric model used for the analysis of time series. It was proposed by Robert Engle [47] in 1982 , based on the autoregressive process with conditional heteroscedasticity, in which the variance of the random component is explained by an appropriately constructed the equation and additional information about the random term is used in the maximum likelihood function. In a broad sense, if the variance of the random component of the explained variable is an ARCH process, then the explained variable itself can also be considered an $\mathrm{ARCH}$ process. The most important advantages of the $\mathrm{ARCH}$ model are the admission of the time-variable conditional variance of the process and the possibility 
of describing the fat-tail effect and grouping the variance. The basic $\mathrm{ARCH}(\mathrm{q})$ model is expressed as in work of Engle [47]:

$$
h_{t}=\propto_{0}+\sum_{i=1}^{q} \propto_{i} \varepsilon_{t-i}^{2}
$$

where:

$h_{t}$-conditional variance;

$\varepsilon_{t} \mid \mathrm{I}_{\mathrm{t}-1} \sim \mathrm{N}\left(0, \mathrm{~h}_{\mathrm{t}}\right)$

$I_{t}$ 一the set of information available in period $t$;

$\alpha_{0}>0, \alpha_{i} \geq 0, i=1, \ldots, q$ and $\sum_{i=1}^{q} \alpha_{i}<1$.

The ARCH process is the base case of a general model GARCH (Generalized Autoregressive Conditional Heteroskedasticity). It is used, inter alia, when the number of $\mathrm{ARCH}$ delays is too high. Compared to the $\mathrm{ARCH}$, it better describes fat-tailed distributions and better fits the empirical data. The model does not allow modeling the leverage effect and taking into account the long memory effect. This model adds lags in the variance to Equation (2). The GARCH(p,q) was first expressed in work of Bollerslev [48]:

$$
h_{t}=\alpha_{0}+\sum_{i=1}^{q} \propto_{i} \varepsilon_{t-i}^{2}+\sum_{j=1}^{p} \beta_{j} h_{t-j}
$$

The following parameters should comply with the conditions to guarantee the variance will be non-negative:

$\alpha_{0}>0, \alpha_{i} \geq 0, \beta_{j} \geq 0, i=1, \ldots, q, j=1, \ldots, p$.

The EGARCH (Exponential GARCH) was described by Nelson [49] and it allows simulating the leverage effect by using an asymmetric information influence curve. It does not require non-negative coefficients and thus takes into account a negative correlation between e.g., the rate of return and the variance. Moreover, it simulates the phenomenon of grouping variances $[50,51]$.

The generalized form of the EGARCH exponential model can be represented by the following equation [52-54]:

$$
\begin{gathered}
y_{t}=\sqrt{h_{t} e_{t}} \\
\log \left(h_{t}\right)=\alpha_{0}+\beta \log \left(h_{t-1}\right)+\gamma\left|\frac{y_{t-1}}{h_{t-1}}\right|+\left|\frac{\theta y_{t-1}}{h_{t-1}}\right|
\end{gathered}
$$

where:

$$
-1<\beta<1 .
$$

The NARCH (non-linear ARCH) is a non-linear GARCH model which is a modification of this model [54]. Eliminates cases in which residues with different signs would compensate each other during the summation operation. NARCH model can be expressed by an Equation (6):

$$
\log \left(h_{t}\right)=\alpha_{0}+\sum_{i=1}^{q} \alpha_{i} \log \left(\varepsilon_{t-q}^{2}\right)
$$

GJR-GARCH is a non-linear model proposed by Glosten, Jagannathan and Runkle [55], which models the asymmetric impact of positive and negative news on variability. The approach is analogous to that of the EGARCH model, with the only difference that in the GJR-GARCH model each arm of the information impact curve is described by a half of the parabola with a different slope. The model is suitable for the approximation of the leverage effect. NARCH model is represented by a following equation:

$$
h_{t}=\alpha_{0}+\sum_{i=1}^{q} \alpha_{i} \varepsilon_{t-i}^{2}+\delta_{i} D_{t-i} \varepsilon_{t-i}^{2}+\sum_{j=1}^{p} \beta_{j} h_{t-j}
$$

where:

$D_{t-i}$-is a dummy variable which takes a value of 1 when $\varepsilon_{t-i}<0$ and 0 when $\varepsilon_{t-i} \geq 0$. when $\delta_{i}>0$ negative shocks will have a larger impact on conditional standard variance than positive shocks [56]. 
The Taylor-Schwert GARCH model is a special variation of the APARCH (Asymmetric Power GARCH-generalization of the GJR-GARCH model) model [57], in which the estimates are not based on variance but standard deviation.

The Taylor-Schwert GARCH $(\mathrm{p}, \mathrm{q})$ is a combination of models proposed by Taylor in 1986 [58] and by Schwert in 1989 [59]. It describes the conditional standard deviation as a distributed lag of the absolute residuals and the lagged conditional standard deviations [60]. The TS-GARCH(p,q) model could be described by an Equation (8):

$$
h_{t}=\alpha_{0}+\sum_{i=1}^{q}\left|\varepsilon_{t-q}\right|+\sum_{j=1}^{p} \beta_{j}\left|h_{t-j}\right|
$$

The TGARCH(p,q) (Threshold GARCH) is a combination of propositions of Zakoian [61] and GJR-GARCH [62]. It presents the conditional variance as a linear piecewise function. The general equation can be described as:

$$
h_{t}=\alpha_{0}+\sum_{i=1}^{q} \alpha_{i} \varepsilon_{t-i}^{2}+\delta_{i} D_{t-i} \varepsilon_{t-i}^{2}+\sum_{j=1}^{p} \beta_{j} h_{t-j}
$$

Markings are similar to GJR-GARCH model.

All models were estimated with maximum likelihood function with GRETL program. The maximum likelihood methods of parameters estimation procedure is given by:

$$
\ln L=-\frac{N}{2} \ln 2 \pi-\frac{1}{2} \sum_{t=1}^{N} \ln h_{t}(\theta)-\frac{1}{2} \sum_{t=1}^{N} \frac{U_{t}^{2}}{h_{t}(\theta)},
$$

where $\ln L$ is the likelihood function, $N$ is the length of the time period, $h_{t}(\theta)$ is the conditional variance described by function:

$$
h_{t}(\theta)=e^{\alpha_{1}+\alpha_{2} \cdot \ln \varepsilon_{t}}
$$

$U_{t}$ denotes the residuals from the regression.

\section{Results}

As mentioned earlier, the analysis of the influence of weather factors was carried out in the cross-section of three dependent variables. Basically, the most interesting from the analysis point of view is the research of the trading volume, also in terms of value. Thus, when modeling the 'change of trading value', it should be stated that the weather factors of significant importance in this case should include: sunshine duration, sum of falls, average daily cloudiness and average daily pressure. We can observe this by analyzing the results listed in Table 1.

The volatility of these factors seems to have a significant impact in the context of the analyzed phenomenon, which in a sense seems to confirm behavioral beliefs in this regard. The sunshine duration is of great importance here, as this variable is indicated as the main element responsible for the broadly understood investment mood.

The multiplicity of variables of significant importance seems to be confirmed in the 'change of value' analysis (Table 2). Although the variable 'sum of falls' ceases to be relevant in this case, the analysis of the atmospheric pressure level becomes extremely important. This weather factor is indicated in many studies as extremely important in generating certain investor behaviors [63,64]. Bassi A., Colacito R. and Fulghieri P. [37] also find that air pressure positively affects our buying and selling transactions. 
Table 1. Parameter values and a significance level of independent variables for individual companies (dependent variable: Change of trading value).

\begin{tabular}{|c|c|c|c|c|}
\hline Parameter & Coefficient & st. Error & $\mathbf{z}$ & $p$-Value \\
\hline \multicolumn{5}{|c|}{ Models for Bedzin, localization-Poznan } \\
\hline \multicolumn{5}{|c|}{ Model: Taylor/Schwert's GARCH(1,1) (Normal) } \\
\hline const & -3.539172 & 0.007038 & -502.823 & $0.0000 * * *$ \\
\hline av. temperature & 0.003201 & 0.000331 & 9.657 & $4.60 \times 10^{-22 * * *}$ \\
\hline sum of falls & 0.001498 & 0.000255 & 5.877 & $4.18 \times 10^{-9 * * *}$ \\
\hline sunshine duration & 0.004999 & 0.000414 & 12.071 & $1.49 \times 10^{-33 * * *}$ \\
\hline time of rainfall & -0.010569 & 0.000486 & -21.774 & $4.48 \times 10^{-105 * * *}$ \\
\hline av. d. cloudiness & 0.004285 & 0.000345 & 12.431 & $1.86 \times 10^{-35 * * *}$ \\
\hline av. d. humidity & 0.003347 & $5.81538 \times 10^{-5}$ & 57.562 & $0.0000^{* * *}$ \\
\hline av. d. pressure & 0.003204 & $8.62110 \times 10^{-6}$ & 371.613 & $0.0000 * * *$ \\
\hline Rt & -7.290827 & 0.402704 & -18.101 & $2.93 \times 10^{-73 * * *}$ \\
\hline Rt-1 & 1.595134 & 0.203706 & 7.831 & $4.86 \times 10^{-15 * * *}$ \\
\hline \multirow{2}{*}{\multicolumn{5}{|c|}{$\begin{array}{l}\text { Models for Energa, localization-Gdansk } \\
\text { Model: Taylor/Schwert's GARCH }(0,1) \text { (Normal) }\end{array}$}} \\
\hline & & & & \\
\hline const & 0.183705 & 0.074777 & 2.457 & $0.0140 * *$ \\
\hline sunshine duration & -0.008466 & 0.004754 & -1.781 & $0.0749 *$ \\
\hline av. d. cloudiness & -0.027144 & 0.010643 & -2.550 & $0.0108^{* *}$ \\
\hline Rt & 3.59017 & 0.466560 & 7.695 & $1.42 \times 10^{-14 * * *}$ \\
\hline Rt-1 & -1.63433 & 0.845982 & -1.932 & 0.0534 * \\
\hline \multirow{2}{*}{\multicolumn{5}{|c|}{$\begin{array}{l}\text { Models for Kogenera, localization-Wroclaw } \\
\text { Model: Taylor/Schwert's GARCH(1,1) (Normal) }\end{array}$}} \\
\hline & & & & \\
\hline const & 11.727742 & 0.013759 & 852.300 & $0.0000^{* * *}$ \\
\hline Rt-1 & 1.086630 & 0.189142 & 5.745 & $9.19 \times 10^{-9 * * *}$ \\
\hline Rt-2 & 2.698861 & 0.161277 & 16.730 & $7.36 \times 10^{-63 * * *}$ \\
\hline av. temperature & 0.006169 & 0.000514 & 11.990 & $3.82 \times 10^{-33 * * *}$ \\
\hline sum of falls & -0.020487 & 0.000683 & -29.970 & $2.28 \cdot 10^{-197 * * *}$ \\
\hline sunshine duration & -0.028149 & 0.000325 & -86.490 & $0.0000^{* * *}$ \\
\hline time of rainfall & -0.018224 & 0.001685 & -10.810 & $2.95 \times 10^{-27 * * *}$ \\
\hline t. of sleety rain falls & -0.070292 & 0.000347 & -202.700 & $0.0000^{* * *}$ \\
\hline av. d. cloudiness & -0.022197 & 0.000296 & -74.920 & $0.0000^{* * *}$ \\
\hline av. d. wind speed & 0.001907 & 0.000322 & 5.924 & $3.14 \times 10^{-9 * * *}$ \\
\hline av. d. pressure & -0.011272 & $2.08507 \times 10^{-5}$ & -540.600 & $0.0000^{* * *}$ \\
\hline \multicolumn{5}{|c|}{$\begin{array}{l}\text { Models for PAK, localization-Konin } \\
\text { Model: GARCH }(0,2)\end{array}$} \\
\hline const & 0.033119 & 0.027313 & 1.213 & 0.2253 \\
\hline Rt & 3.093256 & 1.215881 & 2.544 & $0.0110^{* *}$ \\
\hline sum of falls & -0.013160 & 0.007697 & -1.710 & $0.0873 *$ \\
\hline \multirow{2}{*}{\multicolumn{5}{|c|}{$\begin{array}{l}\text { Models for PGE, localization-Warsaw } \\
\text { Model: Taylor/Schwert's GARCH(2,2) (Normal) }\end{array}$}} \\
\hline & & & & \\
\hline const & 2.067465 & 0.003243 & 637.500 & $0.0000^{* * *}$ \\
\hline Rt & 1.339902 & 0.219941 & 6.092 & $1.11 \times 10^{-9 * * *}$ \\
\hline av. d. pressure & -0.002022 & $8.02564 \times 10^{-6}$ & -252.000 & $0.0000^{* * *}$ \\
\hline \multirow{2}{*}{\multicolumn{5}{|c|}{$\begin{array}{c}\text { Models for Polenerga, localization-Warsaw } \\
\text { Model: GARCH }(0,1)\end{array}$}} \\
\hline & & & & \\
\hline const & -0.173780 & 0.658214 & -1.048 & 0.2946 \\
\hline sum of falls & -0.014658 & 0.844329 & -1.736 & $0.0825 *$ \\
\hline time of snow falls & $-0, .250481$ & 0.010274 & -2.438 & $0.0148^{* *}$ \\
\hline av. d. cloudiness & -0.032682 & 0.019214 & -1.701 & $0.0890 *$ \\
\hline av. d. humidity & 0.004782 & 0.002776 & 1.722 & $0.0850 *$ \\
\hline
\end{tabular}


Table 1. Cont.

\begin{tabular}{ccccc}
\hline Parameter & Coefficient & st. Error & $\mathbf{z}$ & $p$-Value \\
\hline \multicolumn{5}{c}{$\begin{array}{c}\text { Models for Tauron, localization-Katowice } \\
\text { Model: Taylor/Schwert's GARCH(0,1) }\end{array}$} \\
\hline const & -0.632573 & 0.004384 & -144.300 & $0.0000^{* * *}$ \\
Rt & 1.386932 & 0.175820 & 7.888 & $3.06 \times 10^{-15 * * *}$ \\
Rt-1 & -1.035316 & 0.463896 & -2.232 & $0.0256^{* *}$ \\
sunshine duration & 0.003364 & 0.001850 & 1.818 & $0.0690^{*}$ \\
av. d. pressure & 0.000603 & $1.03895 \times 10^{-5}$ & 58.030 & $0.0000^{* * *}$ \\
\hline$*, * * * * *$ represent significance at the $10 \%, 5 \%$, and $1 \%$ levels.
\end{tabular}

Table 2. Parameter values and a significance level of independent variables for individual companies (dependent variable: Change of volume).

\begin{tabular}{|c|c|c|c|c|}
\hline Parameter & Coefficient & st. Error & $\mathbf{z}$ & $p$-Value \\
\hline \multirow{2}{*}{\multicolumn{5}{|c|}{$\begin{array}{l}\text { Models for Bedzin, localization-Poznan } \\
\text { Model: Taylor/Schwert's GARCH(1,1) (Normal) }\end{array}$}} \\
\hline & & & & \\
\hline const & -3.254317 & 0.001494 & -2179.000 & $0.0000^{* * *}$ \\
\hline av. temperature & 0.002003 & 0.000389 & 5.141 & $2.73 \times 10^{-7 * * *}$ \\
\hline sunshine duration & 0.007617 & 0.000607 & 12.551 & $4.00 \times 10^{-36 * * *}$ \\
\hline time of rain fall & -0.009165 & 0.000571 & -16.042 & $6.42 \times 10^{-58 * * *}$ \\
\hline time of snow fall & -0.002042 & 0.000103 & -19.867 & $8.88 \times 10^{-88 * * *}$ \\
\hline t. of sleety rain falls & 0.039741 & 0.000287 & 138.301 & $0.0000^{* * *}$ \\
\hline av. d. cloudiness & 0.007121 & 0.000134 & 53.228 & $0.0000^{* * *}$ \\
\hline av. d. wind speed & -0.010837 & 0.000311 & -34.811 & $1.48 \times 10^{-265 * * *}$ \\
\hline av. d. humidity & 0.002764 & $6.46234 \times 10^{-5}$ & 42.770 & $0.0000^{* * *}$ \\
\hline av. d. pressure & 0.002977 & $1.04497 \times 10^{-5}$ & 284.921 & $0.0000^{* * *}$ \\
\hline $\mathrm{R}_{\mathrm{t}}$ & -7.618912 & 0.246380 & -30.922 & $5.78 \times 10^{-210 * * * *}$ \\
\hline $\mathrm{R}_{\mathrm{t}-1}$ & 1.672107 & 0.071453 & 23.401 & $4.13 \times 10^{-121 * * *}$ \\
\hline $\mathrm{R}_{\mathrm{t}-2}$ & -0.308714 & 0.007982 & -38.673 & $0.0000^{* * *}$ \\
\hline \multicolumn{5}{|c|}{$\begin{array}{l}\text { Models for Energa, localization-Gdansk } \\
\text { Model: GARCH(0,1) }\end{array}$} \\
\hline const & 0.221002 & 0.084224 & 2.624 & $0.0087^{* * *}$ \\
\hline sunshine duration & -0.009169 & 0.005328 & -1.721 & $0.0853 *$ \\
\hline av. d. cloudiness & -0.033288 & 0.011939 & -2.788 & $0.0053^{* * *}$ \\
\hline \multirow{2}{*}{\multicolumn{5}{|c|}{$\begin{array}{c}\text { Models for Kogenera, localization-Wroclaw } \\
\text { TARCH }(1,1) \text { [Zakoian] (Normal) }\end{array}$}} \\
\hline & & & & \\
\hline const & 7.209262 & 0.015296 & 471.302 & $0.0000^{* * *}$ \\
\hline $\mathrm{R}_{\mathrm{t}-1}$ & 0.349934 & 0.031199 & 11.221 & $3.39 \times 10^{-29 * * *}$ \\
\hline$R_{t-2}$ & 2.288645 & 0.135468 & 16.892 & $4.95 \times 10^{-64 * * *}$ \\
\hline av. temperature & 0.002947 & 0.000886 & 3.324 & $0.0009^{* * *}$ \\
\hline sum of falls & -0.017139 & 0.007711 & -2.223 & $0.0262 * *$ \\
\hline sunshine duration & -0.020024 & 0.001888 & -10.601 & $2.87 \times 10^{-26 * * *}$ \\
\hline time of rainfall & -0.019279 & 0.000924 & -20.867 & $1.11 \times 10^{-96 * * *}$ \\
\hline av. d. cloudiness & -0.022925 & 0.000366 & -62.554 & $0.0000 * * *$ \\
\hline av. d. wind speed & 0.011687 & 0.000992 & 11.781 & $5.05 \times 10^{-32 * * *}$ \\
\hline av. d. humidity & 0.000954 & 0.000131 & 7.303 & $2.82 \times 10^{-13 * * *}$ \\
\hline av. d. pressure & -0.007108 & $3.94940 \times 10^{-5}$ & -180.002 & $0.0000^{* * *}$ \\
\hline \multirow{2}{*}{\multicolumn{5}{|c|}{$\begin{array}{l}\text { Models for PAK, localization-Konin } \\
\text { Model: GJR(1,1) [Glosten et al.] (Normal) }\end{array}$}} \\
\hline & & & & \\
\hline const & 0.060590 & 0.031204 & 1.942 & 0.0522 * \\
\hline $\mathrm{R}_{\mathrm{t}-1}$ & -2.064956 & 1.174094 & -1.759 & $0.0786^{*}$ \\
\hline t. of sleety rain falls & -0.228325 & 0.120616 & -1.893 & 0.0584 * \\
\hline
\end{tabular}


Table 2. Cont.

\begin{tabular}{|c|c|c|c|c|}
\hline Parameter & Coefficient & st. Error & $\mathbf{z}$ & $p$-Value \\
\hline \multicolumn{5}{|c|}{$\begin{array}{l}\text { Models for PGE, localization-Warsaw } \\
\text { Model: EGARCH }(0,1) \text { [Nelson] (Normal) }\end{array}$} \\
\hline const & 1.618621 & 0.010467 & 154.600 & $0.0000^{* * *}$ \\
\hline $\mathrm{R}_{\mathrm{t}-1}$ & -0.430435 & 0.069616 & -6.183 & $6.29 \times 10^{-10 * * *}$ \\
\hline $\mathrm{R}_{\mathrm{t}-2}$ & -0.843530 & 0.038754 & -21.770 & $4.86 \times 10^{-105 * * *}$ \\
\hline sum of falls & -0.003927 & 0.001517 & -2.588 & $0.0097^{* * *}$ \\
\hline av. d. cloudiness & -0.008139 & 0.000904 & -9.000 & $2.27 \times 10^{-19 * * *}$ \\
\hline av. d. humidity & 0.000925 & 0.000158 & 5.839 & $5.25 \times 10^{-9 * * *}$ \\
\hline av. d. pressure & -0.001593 & $9.48459 \times 10^{-6}$ & -168.000 & $0.0000^{* * *}$ \\
\hline \multicolumn{5}{|c|}{$\begin{array}{c}\text { Models for Polenerga, localization-Warsaw } \\
\text { Model: NARCH }(2,2) \text { [Higgins and Bera] (Normal) }\end{array}$} \\
\hline const & -2.972253 & 0.047096 & -63.110 & $0.0000 * * *$ \\
\hline $\mathrm{R}_{\mathrm{t}-1}$ & -1.873721 & 0.930263 & -2.014 & $0.0440 * *$ \\
\hline time of snowfall & -0.020318 & 0.010626 & -1.912 & $0.0559 *$ \\
\hline av. d. pressure & 0.002930 & $4.84901 \times 10^{-5}$ & 60.430 & $0.0000^{* * *}$ \\
\hline \multicolumn{5}{|c|}{$\begin{array}{l}\text { Models for Tauron, localization-Katowice } \\
\text { Model: EGARCH(1,1) [Nelson] (Normal) }\end{array}$} \\
\hline const & -0.630458 & 0.005643 & -111.700 & $0.0000^{* * *}$ \\
\hline $\mathrm{R}_{\mathrm{t}-1}$ & -1.208344 & 0.366398 & -3.298 & $0.0010^{* * *}$ \\
\hline av. d. wind speed & -0.007352 & 0.002203 & -3.337 & $0.0008^{* * *}$ \\
\hline av. d. pressure & 0.0006458 & $1.10783 \times 10^{-5}$ & 58.290 & $0.0000^{* * *}$ \\
\hline
\end{tabular}
${ }^{*}, * *, * * *$ represent significance at the $10 \%, 5 \%$, and $1 \%$ levels.

Certainly, the earlier conclusions are not confirmed in the analysis of the rate of return as a dependent variable (Table 3). It's hard to find any clear factor/factors here. There is therefore no clear 'leader' in this case.

Table 3. Parameter values and a significance level of independent variables for individual companies (dependent variable: $\mathrm{R}_{\mathrm{t}}$ ).

\begin{tabular}{|c|c|c|c|c|}
\hline Parameter & Coefficient & st. Error & $\mathbf{z}$ & $p$-Value \\
\hline \multicolumn{5}{|c|}{$\begin{array}{c}\text { Models for Bedzin, localization-Poznan } \\
\text { Model: NARCH }(1,1) \text { [Higgins and Bera] (Normal) }\end{array}$} \\
\hline const & 0.084546 & 0.047439 & 1.782 & 0.0747 * \\
\hline av. temperature & -0.000154 & $7.24542 \times 10^{-5}$ & -2.130 & $0.0332^{* *}$ \\
\hline av. d. humidity & $-7.90603 \times 10^{-5}$ & $4.30186 \times 10^{-5}$ & -1.838 & $0.0661 *$ \\
\hline av. d. pressure & $-7.64290 \times 10^{-5}$ & $4.55627 \times 10^{-5}$ & -1.677 & $0.0935 *$ \\
\hline $\mathrm{R}_{\mathrm{t}-1}$ & -0.192535 & 0.025939 & -7.423 & $1.15 \times 10^{-13 * * *}$ \\
\hline \multirow{2}{*}{\multicolumn{5}{|c|}{$\begin{array}{l}\text { Models for Energa, localization-Gdansk } \\
\text { Model: Taylor/Schwert's GARCH(1,1) (Normal) }\end{array}$}} \\
\hline & & & & \\
\hline const & -0.001108 & $1.37026 \times 10^{-5}$ & -80.851 & $0.0000^{* * *}$ \\
\hline av. temperature & $-8.04759 \times 10^{-5}$ & $6.51081 \times 10^{-6}$ & -12.361 & $4.28 \times 10^{-35 * * *}$ \\
\hline sum of falls & -0.000139 & $2.52435 \times 10^{-6}$ & -55.007 & $0.0000^{* * *}$ \\
\hline sunshine duration & 0.000209 & $1.27964 \times 10^{-5}$ & 16.373 & $3.34 \times 10^{-60 * * *}$ \\
\hline av. d. wind speed & -0.000205 & $3.83829 \times 10^{-6}$ & -53.510 & $0.0000^{* * *}$ \\
\hline av. d. humidity & $2.80800 \times 10^{-5}$ & $1.85648 \times 10^{-6}$ & 15.132 & $1.10 \times 10^{-51 * * *}$ \\
\hline $\mathrm{R}_{\mathrm{t}-1}$ & 0.014289 & 0.000489 & 29.241 & $6.79 \times 10^{-188 * * *}$ \\
\hline \multicolumn{5}{|c|}{$\begin{array}{l}\text { Models for Kogenera, localization-Wroclaw } \\
\text { Model: GARCH }(1,1)\end{array}$} \\
\hline const & -0.001610 & 0.000548 & -2.935 & $0.0033^{* * *}$ \\
\hline sum of falls & 0.000191 & $8.12640 \times 10^{-5}$ & 2.351 & $0.0187^{* *}$ \\
\hline sunshine duration & 0.000160 & $7.30029 \times 10^{-5}$ & 2.195 & $0.0281^{* *}$ \\
\hline
\end{tabular}


Table 3. Cont.

\begin{tabular}{|c|c|c|c|c|}
\hline Parameter & Coefficient & st. Error & $\mathbf{z}$ & $p$-Value \\
\hline \multicolumn{5}{|c|}{$\begin{array}{c}\text { Models for PAK, localization-Konin } \\
\text { Model: GARCH }(1,1)\end{array}$} \\
\hline const & -0.000476 & 0.000465 & -1.024 & 0,3060 \\
\hline t. of snow fall & -0.000457 & 0.000201 & -2.269 & $0,0233^{* *}$ \\
\hline \multicolumn{5}{|c|}{$\begin{array}{l}\text { Models for PGE, localization-Warsaw } \\
\text { Model: EGARCH(0,1) [Nelson] (Normal) }\end{array}$} \\
\hline const & -0.0368702 & 0.000475486 & -77.540 & $0.0000^{* * *}$ \\
\hline av. d. humidity & $-3.73576 \times 10^{-5}$ & $7.01271 \times 10^{-6}$ & -5.327 & $9.98 \times 10^{-8 * * *}$ \\
\hline av. d. pressure & $3.84907 \times 10^{-5}$ & $4.87037 \times 10^{-7}$ & 79.030 & $0.0000 * * *$ \\
\hline \multicolumn{5}{|c|}{$\begin{array}{c}\text { Models for Polenerga, localization-Warsaw } \\
\text { Model: NARCH }(2,2) \text { [Higgins and Bera] (Normal) }\end{array}$} \\
\hline const & 0.020511 & 0.000617 & 33.220 & $5.85 \times 10^{-242 * * *}$ \\
\hline time of rainfall & -0.000202 & 0.000118 & -1.719 & $0.0856^{*}$ \\
\hline av. d. cloudiness & 0.000151 & $4.85516 \times 10^{-5}$ & 3.118 & $0.0018^{* * *}$ \\
\hline av. d. wind speed & 0.000621 & 0.000101 & 6.150 & $7.76 \times 10^{-10 * * *}$ \\
\hline av. d. pressure & $-2.29414 \times 10^{-5}$ & $3.85259 \times 10^{-5}$ & -59.550 & $0.0000^{* * *}$ \\
\hline \multicolumn{5}{|c|}{$\begin{array}{l}\text { Models for Tauron, localization-Katowice } \\
\text { Model: Taylor/Schwert's GARCH( }(0,2) \text { (Normal) }\end{array}$} \\
\hline const & -0.00197544 & 0.000942 & -2.096 & $0.0360 * *$ \\
\hline av. d. wind speed & 0.000646449 & 0.000336 & 1.923 & $0.0544 *$ \\
\hline
\end{tabular}
$*,{ }^{* *},{ }^{* *}$ represent significance at the $10 \%, 5 \%$, and $1 \%$ levels.

Table 4, which is a kind of compilation of indications, allows to distinguish three weather determinants: sunshine duration, average daily cloudiness and average daily preassure. The last mentioned deserves special mention in this case (nearly $64.3 \%$ of responses without the $R_{t}$ variable). Interesting is the lack of influence of the temperature factor, which in most global studies is nevertheless indicated as an important factor of mood.

Table 4. The frequency of occurrence of a given weather factor-collective summary.

\begin{tabular}{cccccc}
\hline \multicolumn{5}{c}{ Dependent Variable } & \\
\hline $\begin{array}{c}\text { Independent } \\
\text { (Weather) Variables }\end{array}$ & $\begin{array}{c}\text { Change of } \\
\text { Trading } \\
\text { Value }\end{array}$ & $\begin{array}{c}\text { Change of } \\
\text { Volume }\end{array}$ & $\mathbf{R}_{\mathbf{t}}$ & $\begin{array}{c}\text { without } \\
\text { Variable } \mathbf{R}_{\mathbf{t}}\end{array}$ & Overall \\
\hline av. temperature & 2 & 2 & 2 & $4 / 14(28.6 \%)$ & $6 / 21(28.6 \%)$ \\
sunshine duration & 4 & 3 & 2 & $7 / 14(50.0 \%)$ & $9 / 21(42.9 \%)$ \\
time of rain fall & 2 & 2 & 1 & $4 / 14(28.6 \%)$ & $5 / 21(23.8 \%)$ \\
time of snow fall & 1 & 2 & 1 & $3 / 14(21.4 \%)$ & $4 / 21(19.0 \%)$ \\
sum of falls & 4 & 1 & 2 & $5 / 14(35.7 \%)$ & $7 / 21(33.3 \%)$ \\
t. of sleety rain falls & 1 & 2 & 0 & $3 / 14(21.4 \%)$ & $3 / 21(14.3 \%)$ \\
av. d. cloudiness & 4 & 4 & 1 & $8 / 14(57.1 \%)$ & $9 / 21(42.9 \%)$ \\
av. d. wind speed & 1 & 3 & 3 & $4 / 14(28.6 \%)$ & $7 / 21(33.3 \%)$ \\
av. d. humidity & 2 & 3 & 3 & $5 / 14(35.7 \%)$ & $8 / 21(38.1 \%)$ \\
av. d. pressure & 4 & 5 & 3 & $9 / 14(64.3 \%)$ & $12 / 21(57.1 \%)$ \\
\hline
\end{tabular}

\section{Discussion}

The aim of the article was verifying the influence of weather factors such as in example average daily cloudiness, average daily pressure, sunshine duration or sum of falls on rates of return, changes of trading volume and changes of trading value for energy sector companies listed on Warsaw Stock Exchange. The first step of the research was implementing OLS regression but no-one time-series give the significant result. Additionally, the White's test for heteroskedasticity or test for time-series residuals normality did not give any satisfying results. Therefore, FGLS regression was used in the next step. The results 
show that this kind of econometric model could not be also implemented for the analysis. Only models based on autoregressive conditional heteroskedasticity gave significant regression parameters. Therefore, it caused the (G)ARCH-type models was used for every analyzed company.

First of all, positive results of regression meaning the existence of possibilities of using econometric models describing processes of shaping stock exchange parameters. It gives investors a possibility to formulating investment strategies on the base of obtain relations. Such a kind of phenomena opens new possibilities for institutional and individual investors in building well-diversified portfolios (including international level). In case of the existence of market inefficiency it could be also used in behavioral portfolio models. Thereby, the energy sector of Warsaw Stock Exchange cannot be efficient in semi-strong and strong forms. There might be suspect that for every developing market such regularity might be assumed. Therefore, it is a direction for further research on this field.

Every estimation process indicated on lack of influence of variables connected to time of falls. The greatest impact of weather factor was observed for changes of trading volume and trading value. Therefore, the hypothesis that weather factors have a significant influence on investors' mood and thanks to that, indirectly on investment decisions is true. Additionally, the relationship between rates of return and weather factors indicates on immediate emotional reactions, which should not be skipped during making decision process.

Both, average dailly cloudiness and pressure have an influence on the human mood and changes of trading reflect the behaviour of investors. So, if the influence of these variables was observed (was the strongest) for analyzed companies, it should be concluded that the weather via investors has the significant impact on stock exchange trading. What is extremely interesting a cloudiness and a pressure have influence on emotional states of individuals. Reversaly to sunshine, cloudiness results apathy, pessimism and lack of vivines, what discourage to making investment decisions. In case of the pressure, only low levels of pressure have an impact on the individual mood and this impact is negative such as for cloudiness.

\section{Conclusions}

The main goal of the article was reached only for autoregressive models. It was proved that the weather factors have a strong influence on the stock exchange, particularly on changes of trading volume and the changes of volume. According to the idea presented in the work [48], volume reflects investors emotions, causing changes in the mood of individuals. Thanks to that, indirectly, it is possible to observe the influence of investors' mood on his financial activity, the greatest impact was obtained for the variables representing investors behaviour such as trading volume and value. It could be concluded that:

- The best approximation for such kind of variables gave the (G)ARCH-type models.

- The weather factors could be significant for the trading factors' regression.

- The variables connected to time of falls have the weakest influence on stock exchange parameters.

It is justified to expand such research for the other stock exchanges in the region of Central and Eastern Europe and other countries, of course, with respect to the specifics of markets, countries, and weather conditions. Therefore, the next analyses will be provided for a wider group of countries.

Author Contributions: Conceptualization, S.M. and G.M.; Formal analysis and methodology, S.M. and G.M.; Investigation, W.T., M.T.-Ł., and A.M.; Writing—original draft, W.T, M.T.-Ł., and A.M. Writing - review and editing, W.T., M.T.-E., A.M., S.M., and G.M. All authors have read and agreed to the published version of the manuscript.

Funding: The project is financed within the framework of the program of the Minister of Science and Higher Education under the name "Regional Excellence Initiative" in the years 2019-2022, project number 001/RID/2018/19, the amount of financing PLN 10,684,000.00. 
Institutional Review Board Statement: Not applicable.

Informed Consent Statement: Not applicable.

Data Availability Statement: Not applicable.

Conflicts of Interest: The authors declare no conflict of interest.

\section{References}

1. Clemmons, L. Introduction to Weather Risk Management, Weather Risk Management. In Markets, Products and Applications; Banks, E., Ed.; Palgrave: New York, NY, USA, 2002; p. 3.

2. Pres, J. Measuring Non-Catastrophic Weather Risks for Businesses. Geneva Pap. Risk Insur. Issues Pract. 2009, 34, 425-439. [CrossRef]

3. Bilan, Y.; Mentel, G.; Streimikiene, D.; Szetela, B. Weather Risk Management in the Weather-VaR Approach. Assumptions of Value-at-Risk Modeling. Econ. Comput. Econ. Cybern. Stud. Res. 2020, 54, 31-48. [CrossRef]

4. Colacito, R.; Hoffmann, B.; Phan, T. Temperature and Growth: A Panel Analysis of the United States. J. Money Crédit. Bank. 2018, 51, 313-368. [CrossRef]

5. Moore, F.C.; Diaz, D.B. Temperature impacts on economic growth warrant stringent mitigation policy. Nat. Clim. Chang. 2015, 5, 127-131. [CrossRef]

6. Moore, F.; Lobell, D. Adaptation potential of European agriculture in response to climate change. Nat. Clim. Chang. 2014, 4, 610-614. [CrossRef]

7. Lu, S.; Bai, X.; Zhang, X.; Li, W.; Tang, Y. The impact of climate change on the sustainable development of regional economy. J. Clean. Prod. 2019, 233, 1387-1395. [CrossRef]

8. Cunningham, M.R. Weather, mood, and helping behavior: Quasi experiments with the sunshine samaritan. J. Personal. Soc. Psychol. 1979, 37, 1947-1956. [CrossRef]

9. Shim, H.; Kim, H.; Kim, J.; Ryu, D. Weather and stock market volatility: The case of a leading emerging market. Appl. Econ. Lett. 2014, 22, 987-992. [CrossRef]

10. Sariannidis, N.; Giannaraki, G.; Partalidou, X. The Effect of Weather on the European Stock Market: The Case of Dow Jones Sustainability Europe Index. Int. J. Soc. Econ. 2016, 43, 943-958. [CrossRef]

11. Sheikh, M.F.; Shah, S.Z.A.; Mahmood, S. Weather Effects on Stock Returns and Volatility in South Asian Markets. Asia-Pac. Financ. Mark. 2017, 24, 75-107. [CrossRef]

12. Hirshleifer, D.; Shumway, T. Good Day Sunshine: Stock Returns and the Weather. J. Financ. 2003, 58, 1009-1032. [CrossRef]

13. Howarth, E.; Hoffman, M.S. A multidimensional approach to the relationship between mood and weather. Br. J. Psychol. 1984, 75, 15-23. [CrossRef]

14. Saunders, E.M. Stock prices and wall street weather. Am. Econ. Rev. 1993, 83, 1337-1345.

15. Kamstra, M.J.; Kramer, L.A.; Levi, M.D. Winter Blues: A SAD Stock Market Cycle. Am. Econ. Rev. 2003, 93, 324-343. [CrossRef]

16. Kamstra, M.J.; Kramer, L.A.; Levi, M.D. Losing Sleep at the Market: The Daylight Saving Anomaly. Am. Econ. Rev. 2000, 90, 1005-1011. [CrossRef]

17. Shafi, K.; Mohammadi, A. Too gloomy to invest: Weather-induced mood and crowdfunding. J. Corp. Financ. $2020,65,101761$. [CrossRef]

18. Fama, E. Efficient Capital Markets: A Review of Theory and Empirical Work. J. Financ. 1970, 25, 383-417. [CrossRef]

19. Nofsinger, J.R. The Psychology of Investing, 4th ed.; Pearson Education Inc.: New York, NY, USA, 2011.

20. Loewenstein, G.F.; Weber, E.U.; Hsee, C.K.; Welch, N. Risk as feelings. Psychol. Bull. 2001, 127, 267. [CrossRef]

21. Zajonc, R.B. Feeling and thinking: Preferences need no inferences. Am. Psychol. 1980, 35, 151. [CrossRef]

22. Johnson, E.J.; Tversky, A. Affect, generalization, and the perception of risk. J. Personal. Soc. Psychol. 1983, 45, 20. [CrossRef]

23. Damasio, A.R. Descartes' Error. Emotions, Reason and a Human Brain; Avon Books: New York, NY, USA, 1995.

24. Cavalheiro, E.A.; Vieira, K.M.; Ceretta, P.S.; de Lima Trindade, L.; Tavares, C.E.M. Misattribution Bias: The Role of Emotion in Risk Tolerance. IUP J. Behav. Financ. 2011, 8, 25.

25. Cajueiro, D.O.; Tabak, B.M. Ranking efficiency for emerging markets. Chaos Solitons Fractals 2004, 22, 349-352. [CrossRef]

26. Rind, B. Effect of Beliefs About Weather Conditions on Tipping. J. Appl. Soc. Psychol. 1996, 26, 137-147. [CrossRef]

27. Cao, N.; Wei, J. Stock Market Returns: A Note on Temperature Anomaly. J. Bank. Financ. 2005, 29, 1559-1573. [CrossRef]

28. Tufan, E.; Hamarat, B. Do cloudy days affect stock exchange returns: Evidence from Istanbul stock exchange. J. Nav. Sci. Eng. 2004, 2, 117-126.

29. Yoon, S.-M.; Kang, S.H. Weather effects on returns: Evidence from the Korean stock market. Phys. A Stat. Mech. Its Appl. 2009, 388, 682-690. [CrossRef]

30. Shahzad, F. Does weather influence investor behavior, stock returns, and volatility? Evidence from the Greater China region. Phys. A Stat. Mech. Its Appl. 2019, 523, 525-543. [CrossRef]

31. Kang, S.H.; Jiang, Z.; Lee, Y.; Yoon, S.-M. Weather effects on the returns and volatility of the Shanghai stock market. Phys. A Stat. Mech. Its Appl. 2010, 389, 91-99. [CrossRef]

32. Mugerman, Y.; Yidov, O; Wiener, Z. By the light of day: The effect of the switch to winter time on stock markets. J. Int. Financ. Mark. Inst. Money 2020, 65, 101197. [CrossRef] 
33. Apergis, N.; Gupta, R. Can (unusual) weather conditions in New York predict South African stock returns? Res. Int. Bus. Financ. 2017, 41, 377-386. [CrossRef]

34. Hirshleifer, D.; Jiang, D.; DiGiovanni, Y.M. Mood beta and seasonalities in stock returns. J. Financ. Econ. 2020, 137, $272-295$. [CrossRef]

35. Daglis, T.; Konstantakis, K.N.; Michaelides, P.G.; Papadakis, T.E. The forecasting ability of solar and space weather data on NASDAQ's finance sector price index volatility. Res. Int. Bus. Financ. 2020, 52, 101147. [CrossRef]

36. Keef, S.P.; Khaled, M.S. Are investors moonstruck? Further international evidence on lunar phases and stock returns. J. Empir. Financ. 2011, 18, 56-63. [CrossRef]

37. Bassi, A.; Colacito, R.; Fulghieri, P. 'O sole mio': An experimental analysis of weather and risk attitudes in financial decisions. Rev. Financ. Stud. 2013, 26, 1824-1852. [CrossRef]

38. Chang, T.; Nieh, C.-C.; Yang, M.J.; Yang, T.-Y. Are stock market returns related to the weather effects? Empirical evidence from Taiwan. Phys. A Stat. Mech. Appl. 2006, 364, 343-354. [CrossRef]

39. Wang, Y.-H.; Lin, C.-T.; Lin, J.D. Does weather impact the stock market? Empirical evidence in Taiwan. Qual. Quant. 2011, 46, 695-703. [CrossRef]

40. Wang, Y.-H.; Shih, K.-H.; Jang, J.-W. Relationship among weather effects, investors' moods and stock market risk: An analysis of bull and bear markets in Taiwan, Japan and Hong Kong. Panoeconomicus 2018, 65, 239-253. [CrossRef]

41. Frühwirth, M.; Sögner, L. Weather and SAD related mood effects on the financial market. Q. Rev. Econ. Financ. 2015, 57, 11-31. [CrossRef]

42. Brzeszczyński, J.; Kelm, R. Ekonometryczne modele rynków finansowych; Wig-Press: Warszawa, Poland, 2002.

43. Szetela, B.; Mentel, G.; Mentel, U.; Bilan, Y. Directional Movement Distribution in the Bitcoin Markets. Eng. Econ. 2020, 31, 188-196. [CrossRef]

44. Hou, J.; Shi, W.; Sun, J. Stock Returns, weather, and air conditioning. PLoS ONE 2019, 14, e0219439. [CrossRef]

45. Peillex, J.; Ouadghiri, I.E.; Gomes, M.; Jaballah, J. Extreme heat and stock market activity. Ecol. Econ. 2021, 179, 106810. [CrossRef]

46. Majewski, S.; Tarczynski, W.; Tarczynska-Luniewska, M. Measuring investors' emotions using econometric models of trading volume of stock exchange indexes. Investig. Manag. Financ. Innov. 2020, 17, 281-291. [CrossRef]

47. Engle, R.F. Autoregressive Conditional Heteroscedasticity with Estimates of the Variance of United Kingdom Inflation. Econometrica 1982, 50, 987. [CrossRef]

48. Bollerslev, T. Generalized autoregressive conditional heteroskedasticity. J. Econ. 1986, 31, 307-327. [CrossRef]

49. Nelson, D.B. Stationarity and Persistence in the GARCH(1,1) Model. Econ. Theory 1990, 6, 318-334. [CrossRef]

50. Dekkers, A.L.M.; Einmahl, J.H.J.; De Haan, L. A Moment Estimator for the Index of an Extreme-Value Distribution. Ann. Stat. 1989, 17, 1833-1855. [CrossRef]

51. Pickands, J., III. Statistical inference using extreme order statistics. Ann. Stat. 1975, 3, 119-131.

52. Shi, X.; Kobayashi, M. Testing for jumps in the EGARCH process. Math. Comput. Simul. 2009, 79, 2797-2808. [CrossRef]

53. Nelson, D.B. Conditional Heteroskedasticity in Asset Returns: A New Approach. Econometrica 1991, 59, 347. [CrossRef]

54. Higgins, M.L.; Bera, A.K. A Class of Nonlinear Arch Models. Int. Econ. Rev. 1992, 33, 137. [CrossRef]

55. Glosten, L.R.; Jagannathan, R.; Runkle, D.E. On the Relation between the Expected Value and the Volatility of the Nominal Excess Return on Stocks. J. Financ. 1993, 48, 1779-1801. [CrossRef]

56. Franses, P.H.; Van Dijk, D. Forecasting stock market volatility using (non-linear) Garch models. J. Forecast. 1996, 15, 229-235. [CrossRef]

57. Ding, Z.; Granger, C.W.J.; Engle, R.F. A long memory property of stock market returns and a new model. J. Empir. Financ. 1993, 1, 83-106. [CrossRef]

58. Taylor, S.J. Modeling Financial Time Series; John Wiley and Sons: Chichester, UK, 1986.

59. Schwert, G.W. Why Does Stock Market Volatility Change Over Time? J. Financ. 1989, 44, 1115-1153. [CrossRef]

60. Bollerslev, T. Glossary to ARCH (GARCH). SSRN Electron. J. 2008. [CrossRef]

61. Zakoian, J.-M. Threshold heteroskedastic models. J. Econ. Dyn. Control. 1994, 18, 931-955. [CrossRef]

62. Echaust, K.; Małgorzata, J. Implied Correlation Index: An Application to Economic Sectors of Commodity Futures and Stock Markets. Eng. Econ. 2020, 31, 4-17. [CrossRef]

63. Digon, E.; Bock, H.B. Suicides and Climatology. Arch. Environ. Health Int. J. 1966, 12, 279-286. [CrossRef]

64. Keller, M.C.; Fredrickson, B.L.; Ybarra, O.; Cote, S.; Johnson, K.; Mikels, J.; Conway, A.; Wager, T. A Warm Heart and a Clear Head: The Contingent Effects of Weather on Mood and Cognition. Psychol. Sci. 2005, 16, 724-731. [CrossRef] 